\title{
Evaluation Method for Thermal Environment in Residential Houses Using Score on Warmth
}

\author{
Yosuke Watanabe $^{1 *}$, Yumiko Araki ${ }^{1}$, Mika Saito ${ }^{2}$, Chaichang Chen $^{2}$, Misa Imazu $^{2}$, Shin-ichi Kagiya ${ }^{3}$, Hiroko Fujimura ${ }^{3}$ \\ Keiko Tsuda ${ }^{3}$, and Shin-ichi Tanabe ${ }^{1}$ \\ ${ }^{1}$ Graduate Student, Department of Architecture, Waseda University, 169-8555 Shinjuku-ku, Tokyo, Japan \\ ${ }^{2}$ Former Graduate Student, Department of Architecture, Waseda University, 169-8555 Shinjuku-ku, Tokyo, Japan \\ ${ }^{3}$ Tokyo Gas Co. Ltd, 105-0013 Minato-ku, Tokyo, Japan
}

\begin{abstract}
The purpose of this study is to verify whether the score on warmth corresponds to the actual rating of subjects with regard to thermal comfort and satisfaction. Experiments were carried out in an experimental house in a climate chamber under five different thermal conditions, in which different combinations of air and floor temperatures were controlled by floor heating or air-conditioning systems. Twenty-four subjects rated their thermal sens2ation and satisfaction in each condition, and evaluated the thermal environment on a 100 -point scale. The results of this experiment are as follows. It was suggested that score on warmth based on operative temperature and floor temperature more appropriately evaluates the living environment in Japan than the Predicted Mean Vote model, which assumes uniformity of the thermal environment. The score on warmth is considered a useful thermal environment index, which evaluates the comfort and satisfaction of residential houses in Japan. The score on warmth was 2.8 points when the percentage of comfort rating was more than $80 \%$, and was 3.0 points when the percentage was more than $90 \%$. In conclusion, these results show that it is possible to predict the risk of catching a cold in winter using the score on warmth.
\end{abstract}

\section{Introduction}

Residential houses built before 1980 in Japan have very poor thermal insulation [1]. Since intermittent air conditioning is common in Japan, low thermal insulation causes temperatures to drop in non-living rooms during winter. It is reported that the coldness of non-living rooms is correlated with the incidence of the common cold among occupants [2]. Therefore, it is necessary to create a healthy home environment for residents and propose an evaluation method. Given this background, Serikawa et al. proposed an evaluation method utilizing the Comprehensive Assessment System for Built Environment Efficiency (CASBEE) Housing Health Checklist [3-4]. However, the evaluation method using score on warmth has not been verified by subjective experiments. Thus, the purpose of this study is to verify whether the score on warmth corresponds to the actual rating. By using the evaluation method proposed by Serikawa et al., it becomes possible to convert the physical quantity of thermal environment obtained by the simulation into a score for evaluating health. Therefore, it will be possible to predict the incidence of colds in winter, which is one index of housing health performance.

Table 1 lists questions on warmth in CASBEE housing health checklists. There are seven questions on warmth in the CASBEE housing health checklist. Total score of this checklist is 21 points. Each questionnaire uses a three-point scale. E. Takayanagi et al. showed that the higher the score, the lower the rate of cold [2].

Table 1. Questions on warmth in CASBEE Housing Health Checklist

\begin{tabular}{|c|l|l|}
\hline 1 & \multirow{2}{*}{$\begin{array}{l}\text { Living } \\
\text { room }\end{array}$} & $\begin{array}{l}\text { Do you feel cold at the startup of heating in the } \\
\text { living room? }\end{array}$ \\
\hline $2 n n$ & \multirow{2}{*}{ Bedroom } & $\begin{array}{l}\text { Do you have trouble sleeping because of coldness } \\
\text { in winter? }\end{array}$ \\
3 & & Do you have dry nose or throat when you wake up? \\
\hline 4 & \multirow{2}{*}{$\begin{array}{l}\text { Sanitary } \\
\text { space }\end{array}$} & $\begin{array}{l}\text { Do you feel cold in the changing room or dressing } \\
\text { room in winter? }\end{array}$ \\
5 & Toilet & Do you feel cold in the bathroom in winter? \\
\hline 7 & $\begin{array}{l}\text { Corridor } \\
\text { Stairs } \\
\text { Closet }\end{array}$ & $\begin{array}{l}\text { Do you feel cold in the toilet in winter? } \\
\text { room? }\end{array}$ \\
\hline
\end{tabular}

Table 2 shows the calculation method of the score on warmth. The score on warmth is determined by summing up the points for operative temperature, floor surface temperature, and difference in operative temperature between a living and non-living room. Each score is calculated as a linear equation between 0 point and a perfect score. If this score is correlated with the actual rating, then it is possible to predict the risk of catching a cold in winter using the score on warmth.

\footnotetext{
* Corresponding author: y.watanabe593@gmail.com
} 
Table 2. Calculation method of score on warmth

\begin{tabular}{|c|c|c|c|c|c|c|c|c|c|c|}
\hline \multirow{3}{*}{\multicolumn{2}{|c|}{\begin{tabular}{|c|}
$\begin{array}{c}\text { 1 Living } \\
\text { room } \\
+1.5 \mathrm{pt}\end{array}$ \\
\end{tabular}}} & & \multicolumn{2}{|c|}{$t_{0}$} & \multicolumn{2}{|c|}{$t_{f}$} & \multicolumn{2}{|c|}{$\Delta \mathrm{t}_{\mathrm{o}}$} \\
\hline & & $\begin{array}{c}0 \\
\mathrm{pt}\end{array}$ & & & $\begin{array}{l}12 \\
{ }^{\circ} \mathrm{C}\end{array}$ & $\begin{array}{l}23 \\
{ }^{\circ} \mathrm{C}\end{array}$ & $\begin{array}{l}17 \\
{ }^{\circ} \mathrm{C}\end{array}$ & $\begin{array}{l}25 \\
{ }^{\circ} \mathrm{C} \\
\end{array}$ & \multirow{2}{*}{\multicolumn{2}{|c|}{ - }} \\
\hline & & \multicolumn{3}{|c|}{$\begin{array}{l}\text { Distribution } \\
\text { of points }\end{array}$} & \multicolumn{2}{|c|}{$0.5 \mathrm{pt}$} & \multicolumn{2}{|c|}{$1.0 \mathrm{pt}$} & & \\
\hline \multirow{2}{*}{\multicolumn{2}{|c|}{$\begin{array}{l}2 \text { Coldness of } \\
\text { bedroom }\end{array}$}} & & $\begin{array}{r}\mathrm{Pe} \\
\mathrm{sc}\end{array}$ & & $\begin{array}{c}0 \\
{ }^{\circ} \mathrm{C}\end{array}$ & $\begin{array}{l}18 \\
{ }^{\circ} \mathrm{C}\end{array}$ & $\begin{array}{l}17 \\
{ }^{\circ} \mathrm{C}\end{array}$ & $\begin{array}{l}25 \\
{ }^{\circ} \mathrm{C}\end{array}$ & \\
\hline & & \multicolumn{3}{|c|}{$\begin{array}{c}\text { Distribution } \\
\text { of points }\end{array}$} & \multicolumn{2}{|c|}{$0.5 \mathrm{pt}$} & \multicolumn{2}{|c|}{$1.0 \mathrm{pt}$} & & \\
\hline \multirow{2}{*}{\multicolumn{2}{|c|}{$\begin{array}{l}3 \text { Dryness of } \\
\text { bedroom }\end{array}$}} & & & & \multirow{2}{*}{\multicolumn{2}{|c|}{-}} & \multirow{2}{*}{\multicolumn{2}{|c|}{-}} & \multirow{2}{*}{\multicolumn{2}{|c|}{ - }} \\
\hline & & \multicolumn{3}{|c|}{$\begin{array}{c}\text { Distribution } \\
\text { of points }\end{array}$} & & & & & & \\
\hline \multirow{2}{*}{\multicolumn{2}{|c|}{$\begin{array}{l}4 \text { Undressing } \\
\text { room }\end{array}$}} & \multicolumn{3}{|c|}{\begin{tabular}{c|c}
0 & $\begin{array}{c}\text { Perfect } \\
\text { pt } \\
\text { score }\end{array}$
\end{tabular}} & \multirow{2}{*}{\multicolumn{2}{|c|}{\begin{tabular}{l|l}
${ }^{\circ} \mathrm{C}$ & ${ }^{\circ} \mathrm{C}$ \\
\end{tabular}}} & \multirow{2}{*}{\multicolumn{2}{|c|}{\begin{tabular}{l|l}
${ }^{\circ} \mathrm{C}$ & ${ }^{\circ} \mathrm{C}$ \\
& $1.0 \mathrm{pt}$
\end{tabular}}} & $\begin{array}{l}14 \\
{ }^{\circ} \mathrm{C} \\
\end{array}$ & $\begin{array}{l}6^{* 1} \\
{ }^{\circ} \mathrm{C} \\
\end{array}$ \\
\hline & & \multicolumn{3}{|c|}{$\begin{array}{c}\text { Distribution } \\
\text { of points }\end{array}$} & & & & & \multicolumn{2}{|c|}{$0.5 \mathrm{pt}$} \\
\hline \multirow{2}{*}{\multicolumn{2}{|c|}{5 Bathroom }} & & & & ${ }^{8} \mathrm{C}$ & $\begin{array}{l}15 \\
{ }^{\circ} \mathrm{C}\end{array}$ & $\begin{array}{l}17 \\
{ }^{\circ} \mathrm{C}\end{array}$ & $\begin{array}{l}25 \\
{ }^{\circ} \mathrm{C}\end{array}$ & $\begin{array}{l}14 \\
{ }^{\circ} \mathrm{C}\end{array}$ & $\begin{array}{l}6^{* 2} \\
{ }^{\circ} \mathrm{C}\end{array}$ \\
\hline & & \multicolumn{3}{|c|}{$\begin{array}{c}\text { Distribution } \\
\text { of points }\end{array}$} & \multicolumn{2}{|c|}{$1.5 \mathrm{pt}$} & & $\mathrm{pt}$ & & $5 \mathrm{pt}$ \\
\hline & & $\begin{array}{c}0 \\
\mathrm{pt}\end{array}$ & & & $\begin{array}{l}8 \\
{ }^{\circ} \mathrm{C}\end{array}$ & $\begin{array}{l}15 \\
{ }^{\circ} \mathrm{C}\end{array}$ & $\begin{array}{l}17 \\
{ }^{\circ} \mathrm{C}\end{array}$ & $\begin{array}{l}25 \\
{ }^{\circ} \mathrm{C}\end{array}$ & $\begin{array}{l}14 \\
{ }^{\circ} \mathrm{C}\end{array}$ & $\begin{array}{l}6^{* 3} \\
{ }^{\circ} \mathrm{C}\end{array}$ \\
\hline & & & $\begin{array}{l}\text { tribu } \\
\text { poir }\end{array}$ & & & $5 \mathrm{pt}$ & & $\mathrm{pt}$ & & $5 \mathrm{pt}$ \\
\hline & & & & & \begin{tabular}{|c|}
8 \\
${ }^{\circ} \mathrm{C}$ \\
\end{tabular} & $\begin{array}{l}15 \\
15 \\
{ }^{\circ} \mathrm{C}\end{array}$ & $\begin{array}{l}17 \\
{ }^{\circ} \mathrm{C}\end{array}$ & $\begin{array}{l}25 \\
{ }^{\circ} \mathrm{C}\end{array}$ & $\begin{array}{l}14 \\
{ }^{\circ} \mathrm{C} \\
\end{array}$ & $\begin{array}{l}6^{* 4} \\
{ }^{\circ} \mathrm{C}\end{array}$ \\
\hline 100 & 100 & & $\begin{array}{c}\text { tribu } \\
\text { poir } \\
\end{array}$ & & & $5 \mathrm{pt}$ & & $\mathrm{pt}$ & & $5 \mathrm{pt}$ \\
\hline & & & & end 0 & $\mathrm{ub}$ & cript & & & & \\
\hline 0 & $\mathrm{f}$ & & 1 & 1 & & $\mathrm{~b}$ & & $\mathrm{t}$ & c & \\
\hline $\begin{array}{l}\text { Oper- } \\
\text { ative } \\
\text { temp. }\end{array}$ & $\begin{array}{l}\text { Floor } \\
\text { surface } \\
\text { temp. }\end{array}$ & & $\begin{array}{l}\text { ing } \\
\text { om }\end{array}$ & $\begin{array}{c}\text { Un } \\
\text { ss } \\
\text { ro }\end{array}$ & & $\begin{array}{l}\text { Bath- } \\
\text { room }\end{array}$ & & ilet & Corr & idor \\
\hline
\end{tabular}

\section{Methods}

\subsection{Conditions of the subjective experiment}

Table 3 lists the conditions of the subjective experiment. The experiment was conducted under five different thermal conditions. Air temperature was controlled by a floor heating system $(\mathrm{FH})$ or an air conditioning system (AC). Under the AC23_FC condition, floor surface temperature was set at $17{ }^{\circ} \mathrm{C}$ by the floor cooling system. Under the AC25_15 condition, the air temperature in nonliving room was set at $15^{\circ} \mathrm{C}$ by the ceiling heating system. Other conditions were not set. Thermal conditions for winter in Japan were simulated outside the model living rooms. Fig. 1 shows the floor plan of the model rooms in the climate chamber. Air temperature (FL+100, 600, $1100,1700,2300 \mathrm{~mm})$. and global temperature $(\mathrm{FL}+1100 \mathrm{~mm})$ were measured at the center and four corners of Rooms A, B, and C.

Inner ear temperature and skin temperature were measured at eight locations on the subjects (head, arm, hand, trunk, thigh, leg, foot, and sole) using thermocouples. During the experiment, the subjects answered questions on a tablet computer to quantify their thermal sensation and thermal comfort. Thermal sensation was described on a seven-point scale like the ASHRAE while thermal comfort was described on a seven-point scale such that the higher the number, the greater the comfort. After the experiment, satisfaction with the living room was described on a seven-point scale, and the subjective score was described on a 100-point scale.

Table 3. Conditions of the subjective experiment

\begin{tabular}{|c|c|c|c|c|c|c|}
\hline \multirow{2}{*}{\multicolumn{2}{|c|}{$\begin{array}{l}\text { Heating systems } \\
\text { Condition }\end{array}$}} & \begin{tabular}{|c|} 
Floor \\
heating
\end{tabular} & \multicolumn{4}{|c|}{ Air conditioning } \\
\hline & & FH23 & \begin{tabular}{|c|} 
AC23 \\
FC
\end{tabular} & $\mathrm{AC} 23$ & $\mathrm{AC} 25$ & $\begin{array}{c}\mathrm{AC} 25 \\
15 \\
\end{array}$ \\
\hline \multirow{2}{*}{$\begin{array}{l}\text { Living } \\
\text { room }\end{array}$} & $\begin{array}{l}\text { Air } \\
\text { temp. }\end{array}$ & \multicolumn{3}{|c|}{$23{ }^{\circ} \mathrm{C}$} & \multicolumn{2}{|c|}{$25^{\circ} \mathrm{C}$} \\
\hline & $\begin{array}{l}\text { Floor } \\
\text { temp. }\end{array}$ & $\begin{array}{l}\text { not } \\
\text { set }\end{array}$ & $17^{\circ} \mathrm{C}$ & $\begin{array}{l}\text { not } \\
\text { set }\end{array}$ & \multicolumn{2}{|c|}{$\begin{array}{l}\text { not } \\
\text { set }\end{array}$} \\
\hline \multirow{2}{*}{$\begin{array}{l}\text { Non- } \\
\text { living } \\
\text { room }\end{array}$} & $\begin{array}{l}\text { Air } \\
\text { temp. }\end{array}$ & \multicolumn{4}{|c|}{ not set } & $15^{\circ} \mathrm{C}$ \\
\hline & $\begin{array}{l}\text { Floor } \\
\text { temp. }\end{array}$ & \multicolumn{4}{|c|}{ not set } & not set \\
\hline \multicolumn{2}{|c|}{$\begin{array}{l}\text { Adaptive room } \\
\text { condition }\end{array}$} & \multicolumn{5}{|c|}{$20{ }^{\circ} \mathrm{C}, 40 \% \mathrm{RH}$} \\
\hline \multicolumn{2}{|c|}{$\begin{array}{l}\text { Outside } \\
\text { condition }\end{array}$} & \multicolumn{5}{|c|}{$5{ }^{\circ} \mathrm{C}, 40 \% \mathrm{RH}$} \\
\hline \multicolumn{2}{|c|}{ Subjects } & \multicolumn{5}{|c|}{8 males and 16 females $(20 \mathrm{~s}-50 \mathrm{~s})$} \\
\hline \multicolumn{2}{|c|}{ Posture } & \multirow{2}{*}{\multicolumn{5}{|c|}{ Sitting on a chair }} \\
\hline \multirow{2}{*}{\multicolumn{2}{|c|}{ Clo value }} & \multirow{2}{*}{\multicolumn{5}{|c|}{0.68 clo }} \\
\hline Metabolic rate & & & & & & \\
\hline
\end{tabular}

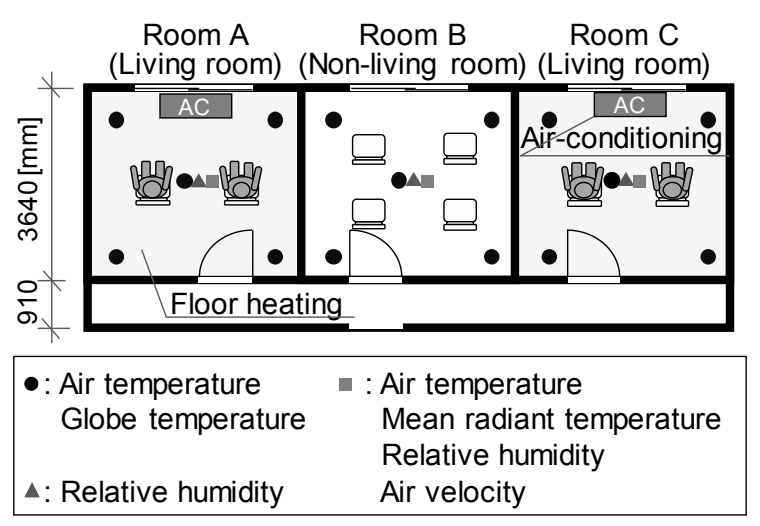

Fig. 1. Plan view of the model rooms in a climate chamber

\subsection{Subjects}

The number of subjects was 24, ranging in age from 21 to 57 years. In the experiment, eight women participated in autumn, and eight women and eight men participated in winter. During the experiment, subjects wore a T-shirt, short pants, underwear, and socks, which are typical clothing at home during winter in Japan.

\subsection{Experimental procedure}

The subjects sat on chairs during the adaptive period. After $30 \mathrm{~min}$ in the adaptive room, the subjects moved to the living room. After $40 \mathrm{~min}$ in the living room, subjects moved to the non-living room. After $10 \mathrm{~min}$, subjects returned to the living room, and sat on the chairs for another $40 \mathrm{~min}$. The first question regarding thermal sensation and thermal comfort was asked $25 \mathrm{~min}$ into the adaptive period. The survey was conducted every $5 \mathrm{~min}$. The exception is when the survey was conducted every 3 min in the non-living room or for $15 \mathrm{~min}$ after returning to living room. 


\section{Results}

\subsection{Indoor thermal measurements}

Table 4 shows the results of thermal environment measurements. The average air and floor surface temperature were calculated from temperature at five locations in the room during the experiments. The thermal conditions were controlled at the target with minimal variation, as indicated by standard deviation. The floor temperatures for the $\mathrm{FH} 23$ and AC23_FC conditions were approximately $27.3{ }^{\circ} \mathrm{C}$ and $17.2{ }^{\circ} \mathrm{C}$, respectively. The air temperature in the non-living room, condition without AC25_15, was $11.7-11.8^{\circ} \mathrm{C}$. The score on warmth in the living room was calculated in the range $2.0-3.0$ points.

Table 4. Results of thermal environment measurements

\begin{tabular}{l|l||c|c|c|c}
\hline \multirow{2}{*}{ Room } & Condition & $\begin{array}{c}\text { Operative } \\
\text { temp. } \\
{\left[{ }^{\circ} \mathrm{C}\right]}\end{array}$ & $\begin{array}{c}\text { Floor } \\
\text { surface } \\
\text { temp. }\left[{ }^{\circ} \mathrm{C}\right]\end{array}$ & $\begin{array}{c}\text { PMV } \\
{[-]}\end{array}$ & $\begin{array}{c}\text { Score on } \\
\text { warmth } \\
{[\mathrm{pt}]}\end{array}$ \\
\hline \hline \multirow{4}{*}{$\begin{array}{l}\text { Living } \\
\text { room }\end{array}$} & FH23 & $23.4(0.3)$ & $27.3(0.2)$ & -0.3 & 3.0 \\
\cline { 2 - 6 } & AC23_FC & $22.8(0.6)$ & $17.2(0.2)$ & -0.3 & 2.0 \\
\cline { 2 - 6 } & AC23 & $23.4(0.5)$ & $21.4(0.2)$ & -0.2 & 2.6 \\
\cline { 2 - 6 } & AC25 & $24.6(0.4)$ & $23.0(0.1)$ & 0.1 & 2.7 \\
\cline { 2 - 6 } & AC25_15 & $24.6(0.5)$ & $22.8(0.4)$ & 0.2 & 2.7 \\
\hline \multirow{4}{*}{$\begin{array}{l}\text { Non- } \\
\text { living } \\
\text { room }\end{array}$} & FH23 & $11.7(0.6)$ & $10.8(0.2)$ & - & 1.0 \\
\cline { 2 - 6 } & AC23_FC & $11.8(0.7)$ & $10.9(0.3)$ & - & 1.0 \\
\cline { 2 - 6 } & AC23 & $11.7(0.6)$ & $10.8(0.2)$ & - & 0.9 \\
\cline { 2 - 6 } & AC25 & $11.8(0.7)$ & $10.9(0.3)$ & - & 0.9 \\
\cline { 2 - 6 } & AC25_15 & $16.2(0.7)$ & $15.3(0.2)$ & -2.4 & 1.8 \\
\hline
\end{tabular}

\subsection{Skin temperature and blood pressure}

Fig. 2 shows the relative values of mean skin temperature. The mean skin temperature was calculated by 7-point skin area formula [5]. The skin temperature in the living room hardly increased when the floor surface temperature was low. The skin temperature of females was significantly lower at low floor surface temperature conditions. The mean skin temperature decreased as the difference in operative temperature between the living room and nonliving room increased. Once the mean skin temperature decreased in the non-living room, it did not return to its former state even when subjects went back to the comfortable living room. It is considered that the temperature difference between rooms in winter caused the decrease in skin temperature.

In all the conditions, a significant rise in systolic blood pressure due to movement into the non-living room was observed in both males and females; when they returned to the living room, their blood pressure dropped significantly. Therefore, movement from the living room to the cold non-living room is considered to cause fluctuations in blood pressure.
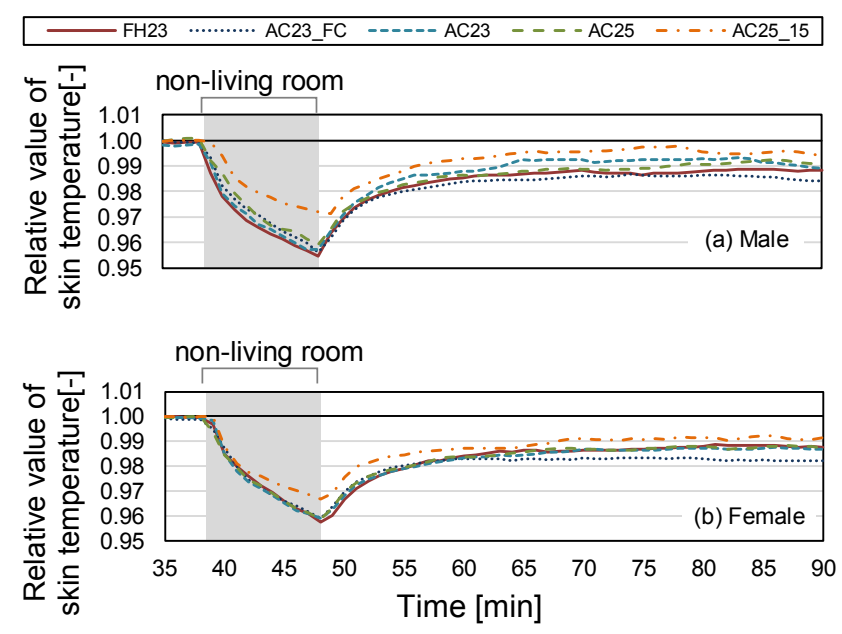

Fig. 2. Relative values of mean skin temperature

\subsection{Thermal sensation, comfort and satisfaction}

Fig.3 shows the thermal sensation and comfort of the whole body. The data points in this figure are the average values for each thermal condition. Regarding the legend, "condition/L" indicates declaration in the living room and "condition/N" indicates declaration in the non-living room. Both males and females who rated whole-body thermal comfort preferred the warmer condition. However, women rated the AC23_FC as uncomfortable.

Fig. 4 shows the satisfaction and subjective score, and Fig. 5 shows satisfaction in living room. There is a correlation between satisfaction and subjective score. There is no contradiction between the warmth score of each condition.

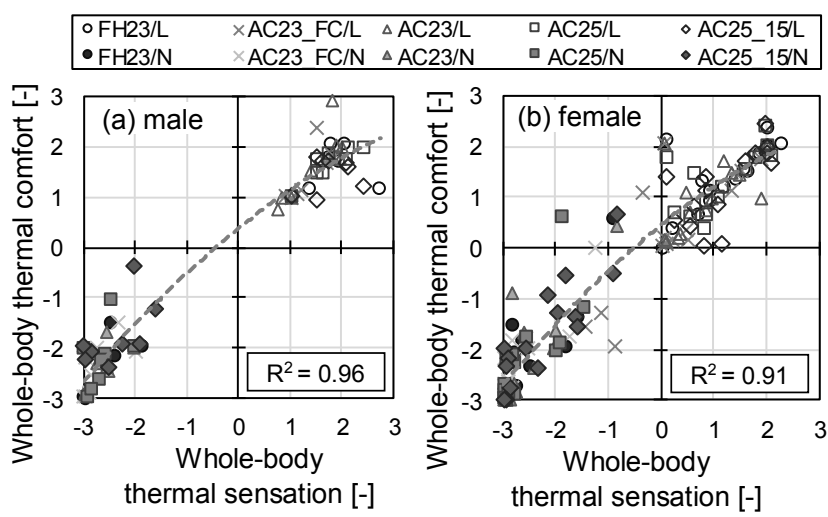

Fig. 3. Whole-body thermal sensation and comfort

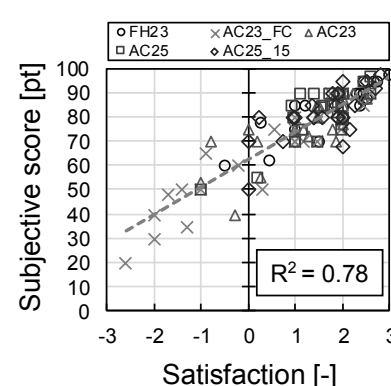

Fig. 4. Satisfaction and subjective score

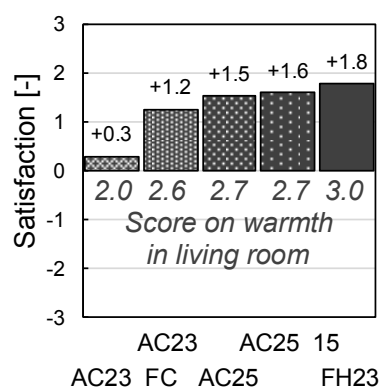

Fig. 5. Satisfaction in living room 


\section{Discussion}

\subsection{Score on warmth}

Fig.6 shows the score on warmth and satisfaction in the living room. The greater the score on warmth than the average of all subjects, the higher the degree of satisfaction. The $\mathrm{R}^{2}$ value correlating with the score on warmth was larger than that with air temperature, floor surface temperature, Predicted Mean Vote model or SET*, which is used as a thermal environment evaluation index [6]. It is suggested that the score on warmth based on operative temperature and floor surface temperature is more appropriate in evaluating the living environment in Japan than these indexes, which assume uniformity of thermal environment. It is considered that the score on warmth is useful as a thermal environment index. In addition, there was a tendency that the number of persons who voted dissatisfaction increased as the score on warmth decreased. Therefore, the score on warmth corresponds to the score of the CASBEE Housing Health Checklists.

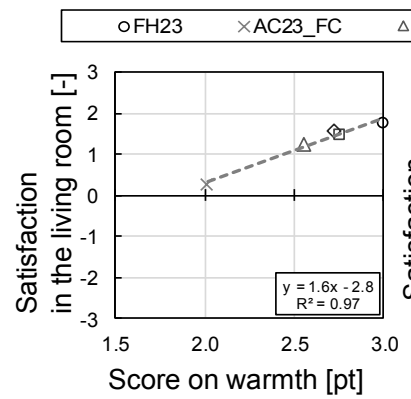

(a) Average of all subjects (b) Average of each subject

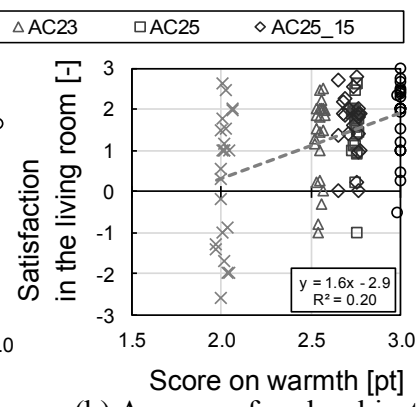

Fig. 6. Score on warmth and satisfaction of living room

\subsection{Score on warmth for thermal comfort}

We investigated the score on warmth value required for residents' comfort in practice. We evaluated the percentage of comfortable ratings compared with the score on warmth by probit analysis to obtain an approximate curve. Fig. 7 shows the percentage of the comfortable side and the score on warmth. The percentage of the comfortable side is defined as "percentage of neutral or comfortable". The minimum value for the $80 \%$ comfort score was 2.1 points for the whole body, 2.8 points for the foot, 2.6 points for the contact, and 2.8 points for all three types. The minimum value for $90 \%$ comfort scores was 2.3 points for the whole body and 3.0 points for all three types. From this, for $80 \%$ whole-body comfort, the score on warmth should be 2.1 points or more, but for the comfort of the whole body, foot, and contact, it should be 2.8 points or more. Likewise, for the $90 \%$ comfortable for all areas, a perfect score of 3.0 points is required.
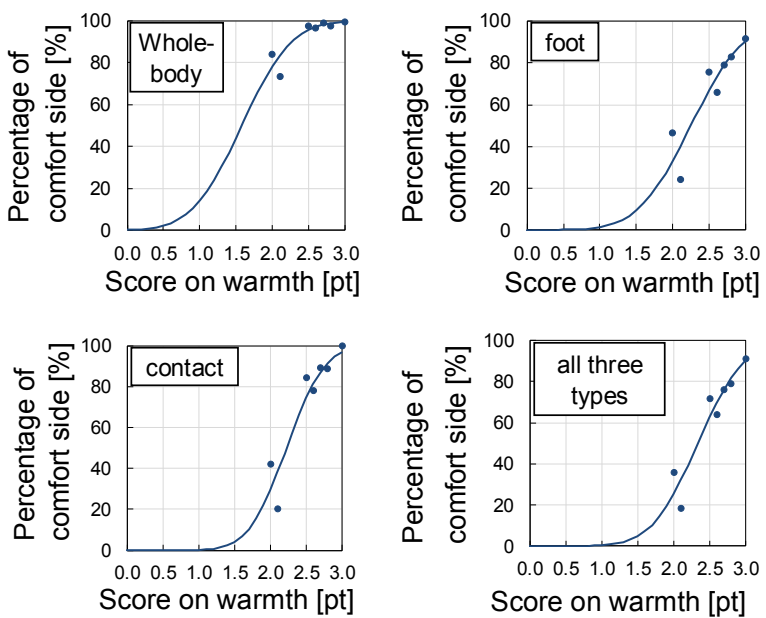

Fig. 7. Percentage of comfort side and score on warmth

\section{Conclusions}

The experiments were conducted under five different thermal conditions, which were combinations of air and floor temperature. Twenty-four subjects rated their thermal sensation and satisfaction in each condition and evaluated the thermal environment on a 100-point scale. The results of this experiment are as follows. The score on warmth accurately evaluates the living environment in Japan. The coldness of the non-living room in residential houses is the cause of decreasing mean skin temperature. The score on warmth was 2.8 points when the percentage of comfort rating was more than $80 \%$, and the score on warmth was 3.0 points when the percentage was more than $90 \%$. In conclusion, it is possible to predict the risk of catching a cold in winter using the score on warmth.

We express gratitude to all parties at Tokyo Gas Co. Ltd. who supported this study, and Editage (www.editage.jp) for English language editing.

\section{References}

1. Housing Renovation Promoting Council, Symposium on long-life renovation of houses, 2016

2. E. Takayanagi, Validation of the Effectiveness of Residential Environment Assessment Tool for Health Promotion (J. Environ. Eng., AIJ, 76 No 670, 2011)

3. Institute for building Environment and Energy Conservation, Outline of CASBEE housing health checklist, 2011

4. M.Serikawa, Proposal of Evaluation Method for Thermal Environment Utilizing CASBEE Housing Health Checklist (J. Environ. Eng., AIJ, 79 No 700, 2014)

5. Hardy, J. D. and E. F. DuBois, The Technique of Radiation and Convection (J. Nutrition, 15, pp. 461475, 1938)

6. P.O.Fanger, Thermal Comfort 、 Danish Technical Press, 1970 